\title{
PENGARUH KOMUNIKASI DAN SIKAP TERHADAP KEPUTUSAN NASABAH MEMILIH BRI CABANG AHMAD YANI MAKASSAR
}

\author{
Abdul Khalik ${ }^{* 1}$, Ibrahim H. Ahmad ${ }^{2}$ \\ Dosen STIE Nobel Indonesia Makassar, STIE YPUP Makassar \\ E-mail: *1 tolouwib1m4@gmail.com, ${ }^{2}$ ibrahimahmad3112@gmail.com
}

\begin{abstract}
This research is intended to learn to learn attitudes towards customer loyalty and to find out the relationship of communication to loyalty at the ahmad yani makassar branch bri bank. the method of data collection in this study uses data collection methods by submitting questionnaires or questionnaires to understand employee communication and relations with investment loyalty at the ahmad yani branch of makassar bri bank. The analytical method used in this research is the method of multiple regression analysis. The results of the study show that the Communication and Attitudes of Employees show that a creditor's communication skills at the Ahmad Yani Branch of BRI Bank BRI have a positive and significant effect on the decision to choose BRI Ahmad Yani Makassar Branch.The dominant variabel that influences customer loyalty is the attitude of employees.
\end{abstract}

Keywords: Communication, Employee Attitudes and Customer Loyalty

\section{PENDAHULUAN}

Perkembangan dalam dunia usaha perbankan dewasa ini telah diwarnai oleh persaingan yang semakin ketat. Hal ini diakibatkan karena adanya arus globalisasi yang semakin terbuka lebar bagi setiap pelaku bisnis. Timbulnya persaingan yang sangat ketat tersebut menyebabkan kalangan usaha saling berlomba untuk dapat menghadapi persaingan dan mendapatkan keunggulan kompetitif. Ndubisi (2007) melaporkan bahwa banyak perusahaan lebih banyak memanfaatkan hubungan yang kuat antara perusahaan dengan pelanggan untuk mendapatkan informasi berharga tentang bagaimana cara terbaik untuk melayani pelanggan dan menjaga mereka agar tidak berpindah ke merak lain untuk bersaing merek.

Dalam dunia perbankan di Indonesia telah terjadi perubahan yang cukup menarik yaitu bergesernya bisnis perbankan, dari perbankan yang melayani perusahaan (corporate banking) menjadi lebih fokus pada melayani perseorangan (consumer banking). Pergeseran ini terjadi setelah krisis ekonomi melanda pada tahun 1998, ketika banyak pelaku bisnis mengalami masalah serius kondisi keuangan usaha yang dijalankan.

Perbankan yang fokus pada consumer banking lebih mampu bertahan daripada perbankan yang fokus pada corporate banking. Semakin banyak bank yang beralih menggarap pasar konsumen membuat persaingan antar bank semakin tinggi. Persaingan yang ketat ini mendorong perbankan untuk menciptakan competitive advantage (Suhardi, 2006).

PT. Bank BRI Cabang Ahmad Yani merupakan salah satu bank konvensional yang memiliki banyak unit dan paling dekat dengan rakyat, sudah tentu sangat memperhatikan pelayanan di bidang perbankan. Dalam upaya meningkatkan keunggulan daya saing di industri perbankan, setiap bank hendaklah mampu membuat suatu 
strategi yang dapat meningkatkan produktivitas dan mutu jasa yang diharapkan. Produktivitas dan mutu menjadi faktor yang sangat penting karena dapat menggambarkan kinerja ekonomis dari perusahaan jasa tersebut.

Kinerja ekonomis dari perusahaan tersebut meliputi dua hal, yaitu kinerja keuangan dan kinerja operasional. Kinerja keuangan dinilai berdasarkan aliran dana, sedangkan kinerja operasional dinilai berdasarkan proses yang sesungguhnya melibatkan konsumen secara langsung dalam bentuk pelayanan khususnya komunikasi dan loyalitas nasabah.

Berdasarkan latar belakang yang telah diuraikan diatas, maka penulis tertarik untuk melakukan penelitian berjudul: "Pengaruh Komunikasi dan sikap terhadap keputusan memilih BRI Cabang Ahmad Yani”.

\section{Rumusan Masalah}

Berdasarkan uraian diatas, maka rumusan masalah dalam penelitian ini adalah :

1. Apakah komunikasi berpengaruh terhadap sikap nasabah?

2. Apakah komunikasi berpengaruh terhadap loyalitas nasabah?

\section{Tujuan Penelitian}

Adapun tujuan Tujuan adalah sebagai berikut adalah;

a. Untuk mengetahui pengaruh sikap terhadap loyalitas nasabah

b. Untuk mengetahui pengaruh komunikasi terhadap loyalitas nasabah

\section{TINJAUAN PUSTAKA}

\section{Pengertian Komunikasi (Comunication)}

Komunikasi adalah proses yang digunakan konsumen dan organisasi pemasaran untuk saling membagi informasi guna mencapai pengertian bersama. Komunikasi penting sekali bagi penerimaan yang menyebar luas akan produk baru (Engel, 2006:382). Dalam kegiatan bisnis, komunikasi pemasaran menjadi sangat penting, dan merupakan bagian dari bauran pemasaran. Karena itu untuk mempertahankan pelanggan dan menarik pelanggan yang baru, perusahaan biasanya melakukan komunikasi pemasaran yang sesuai dengan karakter pelanggan sasarannya. Pada dasarnya, komunikasi dapat menginformasikan dan membuat konsumen potensial menyadari atas keberadaan produk/jasa yang ditawarkan.

Komunikasi dapat berusaha membujuk konsumen potensial agar berhasrat masuk ke dalam hubungan pertukaran (exchange relationship). (Setiadi 2003:235). Dalam komunikasi persuasif (persuasi) ini yang dikehendaki justru perubahan perilaku, keyakinan, dan sikap yang lebih mantap seolah-olah perubahan tersebut bukan atas kehendak komunikator akan tetapi justru atas kehendak komunikator akan tetapi justru atas kehendak komunikan itu sendiri (Setiadi 2003:244)

Menurut Lupiyoadi (2001:111), untuk mengembangkan komunikasi yang efektif maka diperlukan suatu program delapan langkah, yaitu:

1. Mengidentifikasi Audiens Target

2. Menentukan Tujuan Komunikasi

3. Merancang Pesan

4. Menyeleksi Saluran Komunikasi

5. Menetapkan Jumlah Anggaran Promosi

6. Menentukan Bauran Promosi

7. Mengukur Hasil-hasil Promosi

8. Mengelola dan Mengoordinasi Proses Komunikasi

\section{Faktor-Faktor yang Mempengaruhi Komunikasi}

Komunikasi sering mengalami gangguan sehingga proses komunikasi tidak seperti yang diharapkan. Proses komunikasi dipengaruhi oleh beberapa faktor (Potte; \& Perry, 2011). 


\section{Perkembangan}

Agar dapat berkomunikasi efektif dengan seseorang, harus mengerti pengaruh perkembangan usia, baik dari sisi bahasa maupun proses berpikir orang tersebut. Cara berkomunikasi anak usia remaja berbeda dengan anak usia balita.

\section{Persepsi}

Persepsi adalah pandangan pribadi seseorang terhadap suatu kejadian atau peristiwa. Persepsi ini dibentuk oleh pengharapan atau pengalaman. Perbedaan persepsi dapat mengakibatkan terhambatnya komunikasi.

\section{Nilai}

Nilai adalah standar yang mempengaruhi perilaku sehingga penting bagi bidan untuk menyadari nilai seseorang. Seseorang perlu berusaha untuk mengetahui dan mengklarifikasi nilai sehingga dapat membuat keputusan dan interaksi yang tepat dengan klien.

\section{Latar Belakang Sosial Budaya}

Bahasa dan gaya komunikasi akan sangat dipengaruhi oleh faktor- faktor budaya. Budaya juga akan membatasi cara bertindak dan berkomunikasi. Seorang remaja putri yang berasal dari daerah lain ingin membeli makanan khas di suatu daerah.

\section{Emosi}

Emosi merupakan perasaan subjektif terhadap suatu kejadian. Emosi seperti marah, sedih, senang akan dapat mempengaruhi seseorang dalam berkomunikasi dengan orang lain. Seseorang perlu mengkaji emosi klien dengan tepat.

\section{Jenis Kelamin}

Setiap jenis kelamin mempunyai gaya komunikasi yang berbeda. Tanned ( 1990 ) menyebutkan bahwa wanita dan laki-laki mempunyai perbedaan gaya komunikasi.

\section{Pengetahuan}

Tingkat pengetahuan mempengaruhi komunikasi. Seseorang yang tingkat pengetahuannya rendah akan sulit merespons pertanyaan yang mengandung bahasa verbal dengan tingkat pengetahuan yang lebih tinggi. Seseorang perlu mengetahui tingkat pengetahuan klien sehingga dapat berinteraksi dengan baik dan akhirnya dapat memberi asuhan yang tepat kepada klien.

\section{Peran dan Hubungan}

Gaya dan komunikasi sesuai dengan peran dan hubungan antar orang yang berkomunikasi. Cara komunikasi seorang dengan koleganya, dengan cara komunikasi seorang bidan pada klien akan berbeda, tergantung peran. Demikian juga antara orang tua dan anak.

\section{Lingkungan}

Lingkungan interaksi akan mempenganuhi komunikasi yang efektif. Suasana yang bising, tidak ada privasi yang tepat, akan menimbulkan keracunan, ketagangan, dan ketidaknyamanan.

\section{Jarak}

Jarak dapat mempengaruhi komunukasi. Jarak tertentu akan memberi rasa aman dan kontrol.

\section{Citra Diri}

Manusia mempunyai gambaran tertentu mengenai dirinya, status sosial, kelebihan dan kekurangannya. Citra diri terungkap dalam komunikasi.

\section{Kondisi Fisik}

Kondisi fisik mempunyai pengaruh terhadap komunikasi. Artinya, indra pembicaraan mempunyai andil terhadap kelancaran dalam berkomunikasi.

\section{Pengertian Sikap Nasabah}

Pengertian sikap menurut Schiffman dan Kanuk dalam Ujang Sumarwan (2011:166) menyatakan sikap merupakan ungkapan perasaan konsumen tentang suatu obyek apakah disukai atau tidak disukai, dan suka juga bisa menggambarkan kepercayaan 
konsumen terhadap berbagai atribut dan manfaat dari obyek tersebut.

Sedangkan menurut Engel, Blackwell, Miniard dalam Ujang Sumarwan (2011:166) menyatakan bahwa sikap menunjukkan yang konsumen sukai dan yang tidak disukai.

Selanjutnya, menurut Mulyadi Nitisusastro (2011:80) menyatakan bahwa sikap adalah suatu keadaan pada diri konsumen untuk berprilaku suka atau tidak suka ketika dihadapkan kepada satu situasi.

Pengaruh unsur sikap konsumen terhadap produk harus diarahkan kepada perilaku menyukai. Dengan perilaku menyukai paling tidak membenci produk barang atau jasa yang ditawarkan. Perilaku konsumen suka atau tidak suka bisa diakibatkan oleh beberapa hal antara lain tidak mengetahui, tidak mengerti, tidk memahami, atau bahkan tidak memahami tentang manfaat suatu barang dan jasa tersebut.

\section{Faktor-Faktor Yang Mempengaruhi Sikap}

Adapun faktor-faktor yang mempengaruhi pembentukan sikap antara lain: 1. Pengalaman langsung.

Pengalaman individu mengenai objek sikap dari waktu ke waktu akan membentuk sikap tertentu pada individu.

2. Pengaruh keluarga.

Keluarga memiliki peran penting dalam pembentukan sikap maupun perilaku. Keluarga merupakan lingkungan yang paling dekat kerana komsumen melakukan interaksi lebih intensif di banding dengan lingkungan yang lain.

3. Teman sebaya.

Teman sebaya punya peran yang cukup besar terutama bagi anak-anak remaja dalam pembentukan sikap. Adanya kecenderungan untuk mendapatkan penerimaan dari teman-teman sebayanya, mendorong para anak muda mudah di pengaruhi oleh kelompoknya di bandingkan sumber-sember lainnya.

4. Pemasaran langsung.

Mulai banyak perusahaan yang menggukan pemasaran langsung atas produk yang di tawarkan secara tidak langsung berpengaruh dalam pembentukan sikap konsumen.

5. Tayangan media massa.

Media masa yang merupakan sarana komunikasi yang hampir setiap saat dijumpai konsumen dapat membentuk sikap konsumen. Karena peran media ini sangat penting dalam pembentukan sikap, maka pemasar perlu mengetahui media apa yang biasanya dikomsumsi oleh pasar sasarannya dan melalui media tersebut dengan rancangan pesan yang tepat, sikap positif dapat terbentuk.

\section{Pengertian Loyalitas Nasabah}

Komunikasi akan memudahkan nasabah/calon nasabah dalam memperoleh informasi dan memilih produk (pelayanan jasa) yang ditawarkan oleh penyedia jasa yang paling sesuai dengan kebutuhan mereka. Jadi pihak penyedia jasa tidak lepas dari peran dia sebagai komunikator dan promotor yang berusaha untuk mempengaruhi nasabah agar menggunakan produk bahkan menambah tingkat konsumsi produk (pelayanan jasa) yang ditawarkan. Untuk itu pihak penyedia jasa harus menguasai komunikasi pemasaran dengan baik agar dapat berkomunikasi dengan nasabah, sehingga dapat mengambil keputusan penting mengenai pemenuhan keinginan dan kebutuhan nasabah.

Komunikasi yang baik dapat menciptakan hubungan jangka panjang antara nasabah dengan bank. Nasabah dengan mudah memperoleh informasi yang dibutuhkan sehingga nasabah akan merasa aman dan percaya terhadap kredibilitas bank tersebut sehingga akan 
tercipta loyalitas nasabah terhadap bank.

Menurut Durianto, (2001:126) Customer Loyalty merupakan suatu ukuran keterikatan konsumen terhadap sebuah merek. Ukuran ini mampu memberikan gambaran tentang mungkin tidaknya pelanggan beralih ke merek produk yang lain, apabila merek produk tersebut didapati adanya perubahan, baikmenyangkut harga maupun atribut lain.

Menurut Kartajaya, (2010) loyalitas pelanggan berarti kemampuan perusahaan memposisikan produknya di benak pelanggan, dimana perusahaan berusaha memposisikan pelanggan sebagai mitranya dengan cara memantapkan keyakinan pelanggan, selalu berintreraksi, bila perlu mengembangkan demi kemajuan bersama. Seorang pelanggan yang loyal memiliki prasangka yang spesifik mengenai apa yang akan dibeli dan dari siapa. Selain itu loyalitas menunjukkan kondisi daridurasi waktu tertentu dan mensyaratkan bahwa tindakan pembelian terjadi tidak kurang dari dua kali. (Griffin 2003:5).

Definisi yang dikemukakan oleh Oliver (2010:14) loyalitas pelanggan adalah komitmen yang kuat untuk melakukan pembelian ulang atau berlangganan produk yang disukai secara konsisten di masa mendatang, sehingga menimbulkan rangkaian pembelian produk mereka yang sama secara berulang, meskipun pengaruh situasional dan upaya pemasaran berpotensi menyebabkan perpindahan merek. Konsep loyalitas menurut Oliver, menyatakan bahwa tingkat loyalitas konsumen terdiri dari 4 tahap, yakni:

\section{Cognitively Loyal}

Tahap dimana konsumen memiliki pengetahuan langsung maupun tidak langsung konsumen terhadap merek, manfaatnya, dan dilanjutkan dengan melakukan pembelian berdasarkan keyakinan akan superioritas yang ditawarkan.

2. Affectively Loyal

Sikap favorable konsumen terhadap merek yang merupakan hasil konfirmasinya berulang dari harapannya selama tahap cognitively loyal berlangsung.

3. Conatively Loyal

Intensi membeli ulang sangat kuat dan memiliki keterlibatan tinggi yang merupakan dorongan motivasi.

4. Action Loyal

Loyalitas yang bertahan tidak saja karena motivasi yang kuat semata namun telah menjadi suatu keinginan untuk mengatasi segala hambatan yang menghalangi konsumen membeli merek tertentu. Imbalan dari loyalitas bersifat jangka panjang dan kumulatif. Semakin lama loyalitas seorang pelanggan, semakin besar laba yang dapat diperoleh perusahaan dari satu pelanggan ini.

Dari definisi diatas makaloyalitas konsumen harus diciptakan sebagai reaksi positif konsumen terhadap produk/jasa perusahaan. Menurut Sutisna (2003, h.41), loyalitas konsumen dapat dikelompokkan menjadi dua bagian yaitu :

1. Loyalitas merek (brand loyality)

Loyalitas merek dapat didefinisikan sebagai sikap menyenangi terhadap suatu merek yang dipresentasikan dalam pembelian yang konsisten terhadap merek itu sepanjang waktu.

2. Loyalitas toko (store loyality)

Loyalitas toko adalah loyalitas konsumen dalam mengunjungi suatu toko dimana disuatu konsumen biasa membeli merek produk yang diinginkan. Sehingga pelanggan/konsumen enggan berpindah ke toko lain.

HASIL DAN PEMBAHASAN 


\section{Uji Validitas dan Realibilitas}

Uji validitas digunakan untuk mengukur sah (valid) atau tidaknya suatu kuesioner. Suatu kuesioner dikatakan valid jika pertanyaan pada kuesioner mampu mengungkap sesuatu yang akan diukur oleh suatu kuesioner tersebut. Uji validitas dihitung dengan membandingkan nilai $\mathrm{r}$ hitung (correlation item - total correlation) dengan nilai $\mathrm{r}$ tabel. Jika $r$ hitung $>r$ Tabel dan nilai positif maka pertanyaan tersebut dinyatakan valid. Penyebaran kuesioner khusus dalam uji validitas dan realibilitas diberikan kepada 49 orang pegawai Bank Cabang Ahmad Yani Makassar. Dari 49 orang, semua pertanyaan dinyatakan valid dan dapat digunakan untuk melakukan penelitian seperti nampak pada tabel dibawah ini.

\section{Tabel 1. Hasil Uji Validitas}

\begin{tabular}{|c|c|c|c|c|}
\hline Variabel & Pertanyaan & $\begin{array}{c}\text { Correlation item total } \\
\text { correlation }\end{array}$ & r Tabel & Ket \\
\hline \multirow{3}{*}{$\begin{array}{c}\text { Komunikasi } \\
\text { (X1) }\end{array}$} & 1 & 0,557 & 0,3610 & Valid \\
\cline { 2 - 5 } & 2 & 0,467 & 0,3610 & Valid \\
\cline { 2 - 5 } & 3 & 0,643 & 0,3610 & Valid \\
\cline { 2 - 5 } & 5 & 0,624 & 0,3610 & Valid \\
\hline \multirow{4}{*}{$\begin{array}{c}\text { Sikap } \\
\text { Nasabah }\end{array}$} & 2 & 0,624 & 0,3610 & Valid \\
\cline { 2 - 5 } & 3 & 0,467 & 0,3610 & Valid \\
\cline { 2 - 5 } & 4 & 0,624 & 0,3610 & Valid \\
\hline \multirow{3}{*}{$\begin{array}{c}\text { Keputusan } \\
\text { Memilih } \\
(X Y)\end{array}$} & 5 & 0,629 & 0,3610 & Valid \\
\cline { 2 - 5 } & 2 & 0,713 & 0,3610 & Valid \\
\cline { 2 - 5 } & 3 & 0,662 & 0,3610 & Valid \\
\cline { 2 - 5 } & 4 & 0,705 & 0,3610 & Valid \\
\hline
\end{tabular}

Sumber : Bank BRI,2016.

R Tabel diperoleh dari $\mathrm{df}=\mathrm{N}-2$ maka df $47-2=45$ dengan tingkat signifikansi 0,05 untuk uji dua arah, sehingga $r$ tabel $=0,3610$. Dari hasil uji validitas diatas dapat disimpulkan bahwa setiap butir pertayaan dinyatakan valid dan bisa digunakan untuk penelitian.

Selanjutnya, Uji realibilitas adalah data untuk mengukur suatu kuesioner yang merupakan indikator dari variabel. Suatu kuesioner dikatakan reliable atau handal jika jawaban seseorang terhadap pertanyaan adalah konsisten atau stabil dari waktu ke waktu. IBM SPSS versi 22 memberikan fasilitas untuk mengukur realibilitas dengan uji "statistik Cronbach Alpha" (a). Suatu variabel dikatakan realible jika memberikan nilai " Crobach Alpha"> 0,716 .

Berdasarkan hasil ujian yang dilakukan seperti pada tabel tersebut dibawah ini, dan dari semua pertanyaan dalam kuesioner diperoleh semua pertanyaan realiblitas dengan standar " Cronbach Alpha"> 0,716 
Tabel 2. Uji Realibilitas

\begin{tabular}{|c|c|c|c|}
\hline Variabel & Cronbach Alpha & r Tabel & Ket \\
\hline $\mathrm{X} 1$ & 0,672 & 0,716 & Realibel \\
\hline $\mathrm{X} 2$ & 0,756 & 0,716 & Realibel \\
\hline $\mathrm{Y}$ & 0,683 & 0,716 & Realibel \\
\hline
\end{tabular}

Sumber : Olahan SPSS Versi 22.

Berdasarkan hasil "Program SPSS versi 22", dapat disimpulkan bahwa korelasi antara butir 1,2,3,4,dan 5 terhadap total skor tingkat pengembalian kredit menunjukkan signifikan dan valid.

\section{Analisis Regresi Berganda}

Untuk melihat perkembangan pengaruh komunikasi, sikap nasabah terhadap keputusan nasabah memilih
Bank BRI Cabang Ahmad Yani Makassar, maka penulis menggunakan alat analisis yaitu " Metode Analisis Regresi Linier Sederhana ".Penggunakan metode statistik ini diharapkan dapat mengungkapkan sejauh mana pengaruh komunikasi, sikap nasabah terhadap keputusan nasabah memilih pada Bank BRI Cabang Ahmad Yani Makassar. Dari hasil output " SPSS Versi 22 menghasilkan output sebagai berikut ;

Tabel 3. Hasil Ouput Regresi linier Sederhana

Coefficients $^{\mathrm{a}}$

\begin{tabular}{|c|c|c|c|c|c|c|c|}
\hline \multirow[b]{2}{*}{ Model } & \multicolumn{2}{|c|}{$\begin{array}{l}\text { Unstandardized } \\
\text { Coefficients }\end{array}$} & \multirow{2}{*}{\begin{tabular}{|c|}
$\begin{array}{c}\text { Standardize } \\
\mathrm{d} \\
\text { Coefficient } \\
\mathrm{s}\end{array}$ \\
\\
Beta \\
\end{tabular}} & \multirow[b]{2}{*}{$\mathrm{t}$} & \multirow[b]{2}{*}{ Sig. } & \multicolumn{2}{|c|}{$\begin{array}{c}95 \% \text { Confidence } \\
\text { Interval for B } \\
\end{array}$} \\
\hline & B & Std. Error & & & & $\begin{array}{l}\text { Lower } \\
\text { Bound }\end{array}$ & $\begin{array}{l}\text { Upper } \\
\text { Bound }\end{array}$ \\
\hline $1 \quad$ (Constant) & 2.121 & 1.284 & & .094 & .925 & -2.464 & 2.707 \\
\hline Komunikasi ( X1) & .278 & .047 & .476 & 5.919 & .000 & .183 & .373 \\
\hline Sikap (X2) & .480 & .070 & .538 & 6.693 & .000 & .329 & .612 \\
\hline
\end{tabular}

a. Dependent Variabel: memilih BRI

Berdasarkan tabel tersebut diatas dapat diperoleh persamaan regresi linier berganda sebagai berikut ;

\section{$\mathrm{Y}=2.121+0,278 \mathrm{X} 1+0,480 \mathrm{X} 2+$ $1.284 \mathrm{e}$}

Dari persamaan tersebut diatas dapat digambarkan sebagai berikut ;

1. Nilai Konstanta (a) sebesar 2.121 dengan asumsi tingkat kemampuan pendapatan pada Bank BRI Cabang
Ahmad Yani Makassar adalah tetap maka rata-rata tingkat pengembalian kredit pada Bank BRI Cabang Ahmad Yani Makassar sebesar 2.121 satuan, dengan tingkat signifkansinya sebesar 0,925 atau sebesar $92,5 \%$.

2. Nilai koefesien prediktor kemampuan pendapatan (X1) sebesar $=0,278$ satuan . Artinya jika terjadi perubahan kemampuan komunikasi sebesar 1 satuan, maka menyebabkan 
perubahan rata-rata keputusan memilih Bank BRI Cabang Ahmad Yani Makassar sebesar 0,278 satuan, dengan asumsi dasarnya variabel komunikasi adalah konstan atau tetap.

3. Nilai koefisien predictor variabel sikap $\left(\mathrm{X}_{2}\right)$ sebesar 0,480 satuan. Artinya jika terjadi perubahan sikap nasabah sebesar 1 satuan, maka menyebabkan perubahan rata-rata tingkat keputusan nasabah memilih Bank BRI Cabang Ahmad Yani Makassar sebesar $\quad 0,480$ satuan, dengan asumsi dasarnya variabel sikap adalah konstan atau tetap.

\section{Koefisien Determinasi}

Koefisien determinasi digunakan untuk mengetahui kemampuan variabel independen dalam menjelaskan varaibel dependen. Besamya koefisien determinasi dapat dilihat pada $\mathrm{R}$ Square dan dinyatakan dalam persentase. Hasil output koefisien determinasi dapat dilihat pada tabel berikut ini :

\section{Tabel 4. Hasil Output Koefisien Determinasi}

Model Summary

\begin{tabular}{|l|c|c|c|c|}
\hline Model & $\mathrm{R}$ & R Square & $\begin{array}{c}\text { Adjusted R } \\
\text { Square }\end{array}$ & Std. Error of the Estimate \\
\hline 1 & $.885^{\mathrm{a}}$ & .783 & .773 & 1.03872 \\
\hline
\end{tabular}

a. Predictors: (Constant), Sikap, Komunikasi

Dari tabel 10 diatas, dapat diperoleh koefisien $\mathrm{R}$ sebesar 0,885 debgan R Square sebesar 0,783 atau $78,3 \%$ dipengaruhi oleh variabel komunikasi, sikap karyawan, sisanya sebesar 21,3\% dipengaruhi oleh variabel lain yang tidak diteliti pada penelitian ini.

\section{Uji Parsial ( Uji T )}

Uji $\mathrm{T}$ dipergunakan untuk mengkaji apakah variabel independen tersebut secara parsial (sendiri-sendiri) berpengaruh nyata terhadap variabel dependent.

Uji T dapat dilakukan dengan cara membandingkan antara nilai $\mathrm{t}$ tabel dengan nilai $\mathrm{t}$ hitung. Apabila nilai $\mathrm{t}$ hitung lebih besar dari pada nilai nilai $t$ tabel maka variabel independen secara parsial atau sendiri-sendiri tidak mempengaruhi variabel dependen meliputi tingkat pengembalian kredit pada Bank BRI Cabang Ahmad Yani Makassar.

Uji $\mathrm{T}$ diharapkan dapat memberikan gambaran secara spesifik tentang pengaruh masing variabel independent terhadap variabel dependen. Untuk melakukan Uji $\mathrm{T}$ maka diperlukan bantuan " Program Statistik berupa program IMB SPSS Versi 22 sebagaimana terlihat pada hasil output berikut dibawah ini. 
Tabel 5. Output Hasil Uji T (Parsial)

\begin{tabular}{|r|r|r|r|r|}
\multicolumn{5}{|c|}{ Coefficients $^{\mathbf{a}}$} \\
\hline \multirow{2}{*}{$\begin{array}{c}\text { Standardized } \\
\text { Coefficients }\end{array}$} & & & \multicolumn{2}{|c|}{$95 \%$ Confidence Interval for B } \\
\cline { 1 - 3 } Beta & \multicolumn{1}{|c|}{$\mathrm{t}$} & \multicolumn{1}{|c|}{ Sig. } & Lower Bound & Upper Bound \\
\cline { 5 - 6 } & .094 & .925 & -2.464 & 2.707 \\
.476 & 5.919 & .000 & .183 & .373 \\
.538 & 6.693 & .000 & .329 & .612 \\
\hline
\end{tabular}

a. Dependent Variable: Memilih BRI (Y)

Dari tabel tersebut diatas menunjukkan bahwa variabel sebagai berikut :

1. Variabel Komunikasi (X1) dengan nilai $t$ hitung sebesar $1.248 \geq \mathrm{t}$ tabel sebesar 1,984 dengan tingkat signikansinya sebesar 0,219. Ini berarti bahwa variabel komunikasi (X1) dan Sikap nasabah (X2) berpengaruh nyata terhadap variabel keputusan Nasabah Memilih (Y) Bank BRI Cabang Ahmad Yani Makassar dengan tingkat kepercayaan $95 \%$.

2. Variabel Sikap (X2) dengan nilai t hitung $2,596 \geq 1,948$ dengan tingkat signikansinya sebesar
0,13. Artinya variabel sikap nasabah (X2) berpengaruh lebih kecil terhadap keputusan nasabah memilih (Y) Bank BRI Cabang Ahmad Yani Makassar.

\section{Uji Simultan ( Uji F )}

Uji F dilakukan untuk mengetahui apakah variabel independen mampu secara bersama-sama mempengaruhi tingkat pengembalian kredit atau dependen. Berdasarkan hasil perhitungan dengan menggunakan Bantuan Program IMB SPSS versi 22 maka dapat diperoleh hasil output sebagaiman pada tabel berikut dibawah ini :

Tabel 6. Output Hasil Uji F (Simultan)

\begin{tabular}{|c|c|c|c|c|c|c|}
\hline \multicolumn{7}{|c|}{ ANOVA $^{b}$} \\
\hline \multicolumn{2}{|c|}{ Model } & $\begin{array}{l}\text { Sum of } \\
\text { Squares }\end{array}$ & df & Mean Square & $\mathrm{F}$ & Sig. \\
\hline \multirow[t]{3}{*}{1} & Regression & 178.777 & 2 & 89.388 & 82.848 & $.000^{\mathrm{a}}$ \\
\hline & Residual & 49.632 & 46 & 1.079 & & \\
\hline & Total & 228.408 & 48 & & & \\
\hline
\end{tabular}

a. Predictors: (Constant), Sikap, Komunikasi

b. Dependent Variabel: MemilihBRI

Berdasarkan perhitungan pada tabel diatas menunjukkan bahwa $\mathrm{F}$ hitung sebesar 82,848 dengan tingkat signifikansinya sebesar 0,000 . Artinya 
variabel komunikasi (X1), sikap nasabah (X2) dan keputusan nasabah memilih Bank BRI Cabang Ahmad Yani Makassar (Y) secara keseluruhan (simultan) berpengaruh positif dan signifikan terhadap tingkat keputusan nasabah memilih (Y) pada Bank BRI Cabang Ahmad Yani Makassar dengan tingkat kepercayaan sebesar $95 \%$.

\section{KESIMPULAN}

Berdasarkan hasil dan pembahasan yang telah diuraikan tersebut diatas, maka dapat di simpulkan sebagai berikut :

1. Dari hasil penelitian secara parsial menunjukkan bahwa kemampuan komunikasi seseorang kreditur pada Bank BRI Cabang Ahmad Yani Makassar berpengaruh positif dan signifikan terhadap keputusan memilih BRI Cabang Ahmad Yani Makassar.

2. Berdasarkan hasil perhitungan menunjukkan secara simultan variabel komunikasi (X1) Sikap Nasabah (X2) berpengaruh positif dan signifikan terhadap tingkat keputusan nasabah memilih (Y) Bank BRI Cabang Ahmad Yani Makassar.

3. Dari hasil penelitian menunjukkan bahwa faktor yang sangat dominan berpengaruh terhadap keputusan Nasabah Memilih BRI Cabang Ahmad Yani Makassar adalah faktor sikap karyawan.

\section{SARAN}

Berdasarkan hasil dan pembahasan dan kesimpulan tersebut di atas, maka penulis menyarankan beberapa hal antara lain ;

1. Disarankan pada Pimpinan Bank BRI Cabang Ahmad Yani Makassar agar tetap memperhatikan dan mengedepankan skala perioritas utama kemampuan komunikasi dan sikap yang ramah serta perhatian kepada para nasabah Bank BRI Cabang Ahmad Yani Makassar.

2. Disarankan kepada pimpinan Bank BRI Cabang Ahmad Yani Makassar agar tetap mengedepankan komunikasi berupa 5 S (Senyum, Sapa, Salam, Sopan dan Santun)

\section{DAFTAR PUSTAKA}

Ndubisi, Nelson O. 2007. "Relationship Marketing and Customer Loyalty". Marketing Intelligence and Planning. Vol 25. No.1. pg 98 106.

Suhardi, 2006. Pemasaran Jasa Konsep dan Implementasi. Ekonisia Fakultas Ekonomi UII Yogyakarata.

Engel, James et al. 2006. Consumer Behaviour. Mason: Permissions Department, Thomson Business and Economics.

Setiadi, N.J. 2003. Perilaku Konsumen : Konsep dan Implikasi Untuk Strategi dan Penelitian Pemasaran. Kencana. Jakarta.

Lupiyoadi (2001) Manajemen Pemasaran Jasa Teori dan Praktek, Salemba Empat, Jakarta.

Patricia A. Potter \& Perry, Anne G. (2011). Buku Ajar Fundamental Keperawatan (konsep, proses, dan praktik). EGC Penerbit Erlangga. Jakarta.

Sumarwan, Ujang (2011) Perilaku Konsumen. Penerbit. Ghalia Indonesia. Bogor.

Kartajaya, Hermawan. 2010. Perjalan Pemikiran Konsep Pemasaran. Surabaya: Konsumen, Edisi 6 : jilid 1. Penerbit Binarupa Aksara. Jakarta. 
Nitisusastro, Mulyadi.(2011). Perilaku Konsumen. Penerbit. Alfabeta. Bandung.
Oliver, R. L. 2010. Satisfaction: A Behavioral Perpective on The Customer. New York: McGrawHill. 